\title{
Determinan Produktivitas Sosial Perbankan Syariah di Indonesia: Two-Stage Malmquist Productivity Index
}

\author{
Julia Maya Pitalokaㄹ, Nur Cholis², Azizatul Islamiyah, \\ Zulfikar Bagus Pambuko ${ }^{*}$ \\ 1,3,4 Fakultas Agama Islam, Universitas Muhammadiyah Magelang \\ 2 Fakultas Ekonomi, Universitas Muhammadiyah Magelang \\ Email: ${ }^{1}$ pitalokamayal8@gmail.com, ${ }^{2}$ sinawang7@gmail.com, \\ 3azizatulislamiyah121@gmail.com, ${ }^{4 *}$ zulfikar.bp@ummgl.ac.id
}

\begin{abstract}
Islamic banks are obliged to fund and finance the funds to the public. Moreover, Islamic banks are also required to perform social functions. The study aims to analyse the level of social productivity of Islamic Banks in Indonesia and the determinants of it. The data analysis used the Two-Stage Malmquist Productivity Index technique where the first phase uses Malmquist Productivity Index (MPI) and the second uses pooled Tobit regression which applied to 8 BUS from 2013 through 2017. The input variables are the receipt of zakat funds and the charity funds, while the output variables are the use of zakat funds and the charity funds. The results of this study found that Islamic banking has increased productivity in managing social funds by 33.2\% where BJB Syariah became the most productive and BRI Syariah is the lowest. Furthermore, the productivity of Islamic Banks in managing social funds is positively influenced by Return on Assets (ROA) and negatively influenced by the ownership of independent LAZ and Capital Adequacy Ratio (CAR), while Financing to Deposit Ratio (FDR) and bank size have no real effect on the social productivity of Islamic Banks in Indonesia.
\end{abstract}

Keywords: Malmquist Productivity Index, Tobit, Social Productivity, Zakah Funds, Charity Funds

\begin{abstract}
Abstrak
Bank syariah berkewajiban untuk menghimpun dan menyalurkan dana ke masyarakat. Lain daripada itu, bank syariah juga diwajibkan menjalankan fungsi sosial. Tujuan penelitian ini adalah menganalisis tingkat produktivitas sosial perbankan syariah di Indonesia dan faktor yang mempengaruhinya. Analisis data menggunakan teknik Two Stages Malmquist Productivity Index dimana tahap pertama menggunakan teknik Malmquist Producitivity Index (MPI) dan tahap menggunakan pooled tobit regression yang diaplikasikan pada 8 BUS sepanjang periode 2013 - 2017. Variabel input terdiri dari penerimaan zakat dan penerimaan dana kebajikan, sedangkan variabel output-nya terdiri dari penggunaan zakat dan dana kebajikan. Hasil penelitian ini menemukan bahwa perbankan syariah mengalami
\end{abstract}


peningkatan produktivitas dalam mengelola dana sosial sebesar 33,2\% dimana BJB Syariah menjadi yang paling produktif dan BRI Syariah tingkat produktivitasnya paling rendah. Kemudian, produktivitas perbankan syariah dalam mengelola dana sosial dipengaruhi secara positif oleh Return on Asset (ROA) dan dipengaruhi secara negatif oleh kepemilikan LAZ mandiri dan Capital Adequacy Ratio (CAR), sedangkan Financing to Deposit Ratio (FDR) dan ukuran bank tidak memiliki pengaruh yang nyata terhadap produktivitas sosial perbankan syariah.

Kata Kunci: Malmquist Productivity Index, Tobit, Produktivitas Sosial, Dana Zakat, Dana Kebajikan

\section{A. Pendahuluan}

Perjalanan perbankan syariah di Indonesia yang telah beroperasi selama 26 tahun sejak 1992 telah terbukti memberikan warna tersendiri pada sektor keuangan Nasional, khususnya industri perbankan. Perbankan syariah terus mengalami pertumbuhan sejak deregulasi sektor keuangan pada 1988 melalui Pakto 88 dan diikuti dengan beberapa Undang-undang yang mendukung perkembangan dan eksistensinya (Pambuko, 2016). Merujuk pada data OJK (2018), Tabel 1 di bawah menjelaskan perkembangan jumlah Bank Umum Syariah (BUS) dan
Unit Usaha Syariah (UUS) beserta jumlah kantornya. Dari tahun 2014 hingga Maret 2018 diketahui adanya spin-off UUS menjadi BUS, yaitu Bank Aceh Syariah sehingga jumlah BUS bertambah dan sebaliknya jumlah UUS berkurang. Adapun berdasarkan jumlah kantor, diketahui adanya tren yang menurun dalam beberapa dekade terakhir yang dimungkinkan terjadi karena strategi efisiensi operasional mengingat saat ini teknologi sudah sangat maju dan sangat mempermudah proses bisnis perbankan syariah tanpa membutuhkan terlalu banyak bangunan fisik dan tenaga kerja.

Tabel 1. Jaringan Kantor Perbankan Syariah di Indonesia

\begin{tabular}{l|c|c|c|c|c}
\hline & 2014 & 2015 & 2016 & 2017 & $\begin{array}{c}\text { Maret } \\
2018\end{array}$ \\
\hline $\begin{array}{l}\text { Bank Umum Syariah } \\
\text { - Bank }\end{array}$ & 12 & 12 & 13 & 13 & 13 \\
- Kantor & 2.163 & 1.990 & 1.869 & 1.825 & 1.822 \\
\hline $\begin{array}{l}\text { Unit Usaha Syariah } \\
\text { - Bank }\end{array}$ & 22 & 22 & 21 & 21 & 21 \\
- Kantor & 320 & 311 & 332 & 344 & 348 \\
\hline Total Kantor & 2.483 & 2.301 & 2.201 & 2.169 & 2.170 \\
\hline
\end{tabular}


Lebih lanjut, ditinjau dari sisi kinerja keuangan, perbankan syariah juga mengalami pertumbuhan yang relatif signifikan. Tabel 2 berikut yang disarikan dari laporan OJK (2018) menunjukkan penyediaan modal yang dibandingkan dengan aktiva tertimbang menurut risiko semakin besar dan hal ini di atas standar minimal yang ditetapkan oleh OJK. Kemudian dari kemampuan menghasilkan keuntungan, baik dari total asset (ROA) maupun dari rata-rata aktiva produktif (NOM) juga menunjukkan progress yang positif. Dari sisi efisiensi biaya operasional (BOPO) juga semakin membaik dimana rate BOPO semakin menjauhi angka 100\% dari tahun ke tahun. Untuk performa pembiayaan (FDR), perbankan syariah mengalami penurunan jumlah dan hal ini masih di bawah standar yang ditetapkan oleh OJK sebesar 80 - 100\%, meskipun di sisi lain, perbankan syariah telah mampu menekan jumlah risiko pembiayaan bermasalah (NPF) yang semakin kecil.

Tabel 2. Perkembangan Kinerja Keuangan Perbankan Syariah di Indonesia

\begin{tabular}{l|c|c|c|c|c}
\hline Indikator Keuangan & 2014 & 2015 & 2016 & 2017 & $\begin{array}{c}\text { Maret } \\
2018\end{array}$ \\
\hline CAR (\%) & 15.74 & 15.02 & 16.63 & 17.91 & 18.47 \\
\hline ROA (\%) & 0.41 & 0.49 & 0.63 & 0.63 & 1.23 \\
\hline NPF (\%) & 3.38 & 3.19 & 2.17 & 2.58 & 2.54 \\
\hline FDR (\%) & 86.66 & 88.03 & 85.99 & 79.65 & 77.63 \\
\hline BOPO (\%) & 96.97 & 97.01 & 96.22 & 94.91 & 89.90 \\
\hline NOM (\%) & 0.52 & 0.52 & 0.68 & 0.67 & 1.40 \\
\hline
\end{tabular}

Mengamati pertumbuhan positif pada industri perbankan syariah di Indonesia khususnya pada aspek keuangan, maka akan semakin tinggi pula risiko yang akan dihadapi. Dalam konteks ini, OJK selaku pengawas dan pembina pelaku bisnis keuangan di Indonesia telah menyediakan instrumen yang memadai guna mengendalikan risiko tersebut. Hal ini mungkin belum berlaku bagi dana-dana sosial yang dikelola oleh perbankan syariah, seperti dana zakat, infaq, shadaqah, wakaf, dan dana-dana kebajikan lainnya. Sedangkan amanah Undang-undang Nomor 21 Tahun 2008 tentang Perbankan Syariah telah dijelaskan bahwa Bank Syariah dan UUS wajib menjalankan fungsi menghimpun dan menyalurkan dana masyarakat; Bank Syariah dan UUS dapat menjalankan fungsi sosial dalam bentuk lembaga baitul mal, yaitu 
menerima dana yang berasal dari zakat, infak, sedekah, hibah, atau dana sosial lainnya dan menyalurkannya kepada organisasi pengelola zakat; dan Bank Syariah dan UUS dapat menghimpun dana sosial yang berasal dari wakaf uang dan menyalurkannya kepada pengelola wakaf sesuai dengan kehendak pemberi wakaf (RI, 2008).

Oleh karena itu, kajian tentang pengelolaan dana sosial menjadi sangat penting karena lembaga keuangan syariah mempunyai dua peran yang harus berjalan beriringan, yaitu sebagai badan usaha (tamwil) dan badan sosial (maal). Maka dari itu, selain evaluasi kinerja yang berkaitan dengan profit, bank syariah juga membutuhkan evaluasi tentang bagaimana institusi menjalankan perannya sebagai badan sosial yang tentunya mengarah pada kesejahteraan masyarakat.

Studi ini menjadi studi pendahuluan dalam penilaian kinerja perbankan syariah dalam mengelola dana sosial, khususnya dalam penilaian produktivitas. Menurut Hutabarat \& Huseini (2006), produktivitas menjadi faktor penting dalam keberhasilan perusahaan, karena di samping mempengaruhi biaya produksi juga berpengaruh terhadap motivasi dan kepuasan karyawan serta kepercayaan konsumen. Bahkan lebih jauh, produktivitas juga mampu menjadi indikator utama dalam menilai kemampuan bersaing (Hidayati, 2005) dan menjadi faktor yang diperhitungkan dalam pengambilan keputusan (Hseu \& Shang, 2005).

Adapun riset-riset yang berkaitan dengan perbankan syariah, utamanya dalam konteks analisis produktivitas finansial (keuangan) ditemukan bahwa bank syariah produktivitasnya terus meningkat (Afiatun \&\& Wiryono, 2010; Othman et al., 2013; Pontoh, 2016). Bank syariah semakin meningkat produktivitasnya setelah spin off (Norfitriani, 2016). Setelah merger, produktivitas perbankan syariah juga semakin baik (Sufian \& Kamarudin, 2017). Office chanelling produktivitasnya lebih rendah daripada full-fledged banking (Sufian, 2007). Bank syariah domestik tidak lebih produktif dari bank syariah asing (Kamarudin et al., 2017). Bahkan pada konteks dan waktu yang berbeda, bank syariah juga mengalami penurunan produktivitas (Bahrini, 2015; Johnes et al., 2015; Sufian, 2005).

Berkaitan dengan determinan produktivitas perbankan syariah, penelitian mengambil lima variabel 
internal yang akan diuji pengaruhnya terhadap tingkat produktivitas, yaitu kepemilikan LAZ mandiri, Financing to Deposit Ratio (FDR), Capital Adequacy Ratio (CAR), Return on Asset (ROA), dan ukuran bank. Kepemilikan LAZ mandiri merupakan variabel dummy yang menjelaskan tentang pengelolaan dana sosial yang dilakukan secara mandiri oleh perbankan syariah atau diserahkan kepada LAZ independen yang tidak terafiliasi dengan perbankan syariah. Merujuk pada Undang-undang Nomor 21 Tahun 2008 tentang perbankan syariah (RI, 2008), produktivitas pengelolaan dana sosial oleh perbankan akan semakin baik jika diserahkan kepada LAZ independen.

Financing to Deposit Ratio (FDR) mencerminkan besarnya alokasi pembiayaan dari dana yang dihimpun dari masyarakat (Riyadi, 2015). Capital Adequacy Ratio (CAR) mencerminkan rasio kecukupan modal yang menunjukkan kemampuan perbankan dalam menyediakan dana yang digunakan untuk mengatasi kemungkinan risiko kerugian (Rivai, Veithzal, \& Idroes, 2007). Return on Asset (ROA) menunjukkan besarnya pendapatan bersih bank syariah jika dibandingkan dengan nilai aset yang dikuasai (Kasmir, 2010). Ukuran bank mencerminkan kecenderungan untuk mengelola dana lebih besar yang diproksikan dengan nilai total asset. Oleh karena itu, peningkatan atau penurunan produktivitas sosial perbankan syariah diasumsikan mampu dipengaruhi oleh besarnya pembiayaan yang disalurkan, besarnya modal yang disetor, besarnya keuntungan, dan besarnya penguasaan asset oleh perbankan syariah, atau sebaliknya.

Lain daripada itu, riset yang berkaitan dengan produktivitas sosial atau pengelolaan dana sosial sepanjang pengamatan peneliti belum pernah dilakukan. Berdasarkan gap research di atas, penelitian ini akan mengukur tingkat produktivitas sosial dan faktorfaktor yang mempengaruhinya pada periode 2013 - 2017 menggunakan pendekatan Two-Stage Malmquist Productivity Index.

\section{B. Metode Penelitian}

a. Objek dan Variabel Penelitian Objek penelitian adalah 8 Bank Umum Syariah (BUS), meliputi: 1) Bank Muamalat Indonesia, 2) Bank Syariah Mandiri, 3) Bank Mega Syariah, 4) BRI Syariah, 5) BNI Syariah, 6) BCA Syariah, 7) Bank Jabar dan Banten Syariah, dan 8) 
Bank Victoria Syariah. Pemilihan objek penelitian ini didasarkan pada ketersediaan data yang dapat diakses oleh peneliti. Data diperoleh menggunakan metode dokumentasi dalam bentuk data tahunan yang diakses dari laporan tahunan masing-masing bank syariah pada tahun 2013 - 2017.

Analisis terhadap determinan produktivitas sosial pada perbankan syariah di Indonesia dilakukan dalam dua tahap. Pertama, Malmquist Productivity Index (MPI) dengan pendekatan intermediasi untuk mengukur tingkat produktivitas sosial sebagaimana digunakan oleh Norfitriani (2016). Variabel input (X) yang digunakan adalah penerimaan dana zakat (Xl) dan penerimaan dana kebajikan (X2). Kemudian, variabel output (Y) yang digunakan adalah penggunaan dana zakat (Yl) dan penggunaan dana kebajikan (Y2). Kedua, skor hasil pengukuran MPI akan digunakan sebagai variabel dependen yang dianalisis menggunakan model Pooled Tobit untuk menganalisis determinan tingkat produktivitas sosial perbankan syariah di Indonesia. Variabel independen yang akan diuji pengaruhnya adalah kepemilikan LAZ mandiri (dummy 0 dan 1), ROA, FDR, CAR, dan ukuran bank.

Tabel 3. Variabel Penelitian

\begin{tabular}{|c|c|c|}
\hline $\begin{array}{l}\text { Variabel } \\
\text { Penelitian }\end{array}$ & Cakupan & Indikator \\
\hline Dependen & Produktivitas Sosial & $\begin{array}{l}\text { Input: } \\
\text { Penerimaan Dana Zakat } \\
\text { Penerimaan Dana Kebajikan } \\
\text { Output: } \\
\text { Penggunaan Dana Zakat } \\
\text { Penggunaan Dana Kebajikan }\end{array}$ \\
\hline Independen & $\begin{array}{l}\checkmark \text { Kepemilikan LAZ } \\
\text { Mandiri (Dummy) } \\
\checkmark \text { Financing to Deposit } \\
\quad \text { Rasio (FDR) } \\
\checkmark \text { Capital Adequacy Rasio } \\
\quad \text { (CAR) } \\
\checkmark \text { Return on Asset (ROA) } \\
\checkmark \text { ukuran bank (TA) }\end{array}$ & $\begin{array}{l}0=\text { kepemilikan LAZ independen } \\
\mathrm{l}=\text { kepemilikan LAZ mandiri }\end{array}$ \\
\hline
\end{tabular}


b. Malmquist Productivity Index (MPI)

Analisis data first stage dalam penelitian ini menggunakan teknik nonparametrik berupa teknik Malmquist Productivity Index (MPI) yang dikembangkan oleh Fare et al., (1994). Pengukuran Malmquist Productivity Index dilakukan dengan alat bantu analisis DEAP (Data Envelopment Analysis Program) 2.l (Coelli et al., 2005). Metode ini dapat mendekomposisi perubahan produktivitas menjadi perubahan efisiensi teknis dan perubahan teknologi.

\section{Total Factor Productivity (TFP)} merupakan perkalian dari indeks perubahan efisiensi, yaitu semua indikasi akan dihitung relatif dengan tahun sebelumnya, sehingga estimasi hasil akan dimulai pada $\mathrm{t}+1$ (Fare et al., 1994). Untuk kriteria Malmquist Index adalah bila nilai malmquist index lebih kecil dari 1 maka terjadi penurunan produktivitas, bila lebih dari 1 maka terjadi peningkatan produktivitas, sedangkan bila sama dengan 1 maka tidak ada perubahan kinerja. Dalam pengukuran produktivitas lembaga keuangan, pendekatan output orientated dinilai lebih tepat digunakan karena berorientasi untuk memaksimalkan output dengan memanfaatkan input-input yang tersedia.

\section{c. Regresi Tobit}

Analisis data second stage dalam penelitian ini menggunakan metode pooled Tobit untuk menganalisis determinan tingkat produktivitas social perbankan syariah di Indonesia. Dengan terlebih dahulu mendapatkan nilai produktivitas pada tahap pertama menggunakan metode MPI, maka nilai tersebut akan dianalisis dengan beberapa variabel independen untuk mengetahui pengaruh variabel-variabel tersebut terhadap tingkat produktivitas. Metode Tobit digunakan karena data yang digunakan dalam penelitian ini merupakan data yang censored. Jika metode Ordinary Least Square (OLS) digunakan dengan data tersebut, maka hasil regresi akan menjadi bias dan tidak konsisten (Fathony, 2012).

Menurut Endri (2008), metode Tobit mengasumsikan bahwa variabelvariabel bebas tidak terbatas nilainya (non-censured); hanya variabel tidak bebas yang censured; semua variabel (baik bebas maupun tidak bebas) diukur dengan benar; tidak ada autocorrelation; tidak ada heteroscedascity; tidak ada multikolinearitas yang sempurna; dan 
model matematis yang digunakan menjadi tepat. Struktur data seperti ini dinamakan data tersensor (censored data). Persamaan regresi Tobit dalam penelitian ini adalah sebagai berikut:

$$
\begin{aligned}
\mathrm{TFP}_{\mathrm{it}}= & \boldsymbol{\beta}_{0}+\boldsymbol{\beta}_{1}\left(\text { dummy_LAZ }_{\mathrm{it}}+\right. \\
& \boldsymbol{\beta}_{2}(\mathrm{FDR})_{\mathrm{it}}+\boldsymbol{\beta}_{3}(\mathrm{CAR})_{\mathrm{it}}+ \\
& \boldsymbol{\beta}_{4}(\mathrm{ROA})_{\mathrm{it}}+\boldsymbol{\beta}_{5}(\mathrm{TA})_{\mathrm{it}}+\mathrm{u}_{\mathrm{it}}
\end{aligned}
$$

Keterangan:

TFP = skor MPI (tingkat produktivitas)

$\mathrm{ROA}=$ return on asset

FDR = financing to deposit ratio

$\mathrm{CAR}=$ capital adequacy ratio

TA $=$ total asset

\section{Hasil Penelitian dan Pembahasan}

a. First Stage: Pengukuran Tingkat Produktivitas Sosial dengan Malmquist Productivity Index (MPI)
Analisis produktivitas sosial perbankan syariah dengan Malmquist Productivity Index (MPI) dilakukan pada 40 DMU (Decision Making Unit) yang berorientasi pada output (output orientated) dengan menggunakan asumsi VRS (Variable Return to Scale). Asumsi VRS memungkinkan adanya konklusi bahwa penambahan 1 unit input tidak harus menghasilkan tambahan sebesar 1 unit output yang lebih besar atau lebih kecil dari 1 (Banker, Charnes, \& Cooper, 1984). Hasil pengukuran tingkat produktivitas sosial pada 8 BUS selama periode 2013-2017 dapat dilihat dalam tabel 4 berikut:

Tabel 4. Tingkat Produktivitas Sosial Perbankan Syariah Periode 2013-2017

\begin{tabular}{lccccc}
\hline \multicolumn{1}{c}{ BUS } & EFFCH & TECHCH & PECH & SECH & TFPCH \\
\hline Muamalat & 0.968 & 1.409 & 1.000 & 0.968 & 1.365 \\
Syari'ah Mandiri & 0.773 & 1.596 & 1.000 & 0.773 & 1.233 \\
Mega Syari'ah & 1.000 & 1.216 & 1.000 & 1.000 & 1.216 \\
BRI Syari'ah & 0.887 & 1.086 & 1.000 & 0.887 & 0.963 \\
BNI Syari'ah & 1.010 & 1.063 & 1.000 & 1.010 & 1.074 \\
BCA Syari'ah & 0.723 & 1.698 & 1.000 & 0.723 & 1.228 \\
BJB Syari'ah & 2.335 & 1.364 & 1.000 & 2.335 & 3.186 \\
Victoria Syari'ah & 0.733 & 1.639 & 0.959 & 0.764 & 1.201 \\
\hline Mean & 0.977 & 1.364 & 0.995 & 0.982 & 1.332 \\
Min & 0.723 & 1.063 & 0.959 & 0.764 & 0.963 \\
Max & 2.335 & 1.698 & 1.000 & 2.335 & 3.186 \\
\hline Number of Increase & 2 & 8 & 0 & 2 & 7 \\
\hline
\end{tabular}




\begin{tabular}{lccccc}
\hline $\begin{array}{l}\text { Number of Decrease } \\
\text { Number of no change }\end{array}$ & 5 & 0 & 1 & 5 & 1 \\
\hline Periode Observasi & 1 & 0 & 7 & 1 & 0 \\
$2013-2014$ & 1.421 & 2.190 & 1.000 & 1.421 & 3.113 \\
$2014-2015$ & 0.824 & 0.565 & 0.793 & 1.039 & 0.465 \\
$2015-2016$ & 1.232 & 1.649 & 1.250 & 0.986 & 2.032 \\
$2016-2017$ & 0.631 & 1.697 & 0.988 & 0.639 & 1.072 \\
\hline
\end{tabular}

Berdasarkan data yang tersaji pada tabel 4 di atas diketahui bahwa 7 BUS mengalami peningkatan produktivitas sosial sepanjang periode observasi (TFPCH > 1) dan 1 BUS mengalami penurunan produktivitas sosial $(\mathrm{TFPCH}<1)$. BUS yang mengalami penurunan produktivitas adalah BRI Syariah dengan penurunan sebesar $-3,7 \%$ $(0,963)$. Adapun diantara 7 BUS yang mengalami peningkatan produktivitas sosial, BJB Syariah adalah bank syariah yang mengalami pertumbuhan tertinggi, yaitu sebesar 218,6\% (3,186). Hasil yang positif ini ditopang oleh peningkatan technological change (TECHCH) sebesar $36,4 \%$ dan peningkatan efficiency change (EFFCH) sebesar 133,5\%. Peningkatan efisiensi sepenuhnya disebabkan oleh perbaikan aspek manajerial dalam pengelolaan dana sosial. Kemudian, untuk 6 BUS lainnya, secara umum pencapaian produktivitas sosial ditopang oleh kemampuan perbankan syariah dalam mengikuti perkembangan teknologi dan informasi yang dapat dilihat dari seluruh nilai TECHCH yang lebih dari 1 , sedangkan dari sisi efisiensi relatif belum baik karena 5 BUS mengalami inefisiensi $(\mathrm{EFFCH}<1)$. Temuan ini sejalan dengan Omar et al. (2007) dan Asian Banker Research (2003) yang mengungkapkan bahwa bank besar tidak selalu tampil lebih baik dalam hal produktivitas.

Secara umum, produktivitas sosial perbankan syariah di Indonesia sepanjang periode observasi adalah meningkat sebesar 33,2\%. Hal ini tercermin dari nilai rata-rata Total Factor Productivity Change (TFPCH) pada periode 2013-2017 sebesar 1,332. Meningkatnya produktivitas sosial ini merupakan dampak dari peningkatan Technological Change (TECHCH) atau perubahan teknologi sebesar 36,4\% (1,364) dan penurunan Efficiency Change $(\mathrm{EFFCH})$ atau inefisiensi sebesar $-2.3 \%$. Inefisiensi pada perbankan syari'ah dibentuk oleh komponen Pure Efficiency Change $(\mathrm{PECH})$ atau aspek managerial 
sebesar $-0.5 \%$ dan Scale Efficiency Change (SECH) sebesar -1.8\%. Hal ini mendukung temuan Suzuki \& Sastrosuwito (2011) yang menemukan bahwa produktivitas bank-bank komersial Indonesia disebabkan oleh perubahan teknologi bukan efisiensi teknis yang menyiratkan pentingnya mengembangkan teknologi dan inovasi dalam mencapai produktivitas sektor perbankan.

Selanjutnya berdasarkan analisis produktivitas sosial antar waktu, perubahan produktivitas sosial terbaik terjadi pada periode 2013 - 2014, yaitu meningkat sebesar 211,3\% yang ditopang oleh peningkatan efisiensi dan perubahan teknologi. Namun euphoria ini tidak dapat dipertahankan pada tahun berikut dimana terjadi penurunan produktivitas yang cukup signifikan pada periode 2014 - 2015 sebesar $-53,5 \%$. Pencapaian yang relatif buruk pada tahun 2015 mampu diperbaiki oleh perbankan syariah dimana pada 2 periode selanjutnya terjadi peningkatan produktivitas, yaitu pada 2015 - 2016 sebesar $103,2 \%$ dan pada 2016 - 2017 sebesar 7,2\%. Seluruh hasil analisis tentang produktivitas sosial di atas mendukung temuan Putra et al., (2018) yang telah melakukan riset sejenis dengan data panel dan objek yang sama dengan penelitian ini.

b. Second Stage: Model Pooled Tobit Pengujian terhadap determinan atau factor yang mempengaruhi produktivitas sosial pada perbankan syariah periode 2013-2017 dengan metode Tobit, dapat dilihat pada tabel 5 berikut.

Tabel 5. Hasil Analisis Regresi Tobit

\begin{tabular}{lrrrr}
\hline \hline \multicolumn{1}{r}{ Variable } & Coefficient & Std. Error & z-Statistic & Prob. \\
\hline \hline C & 85.31752 & 93.96934 & 0.907929 & 0.3639 \\
D_LAZ & -16.73544 & 7.117218 & -2.351402 & $0.0187^{*}$ \\
FDR & 0.124143 & 0.425954 & 0.291447 & 0.7707 \\
CAR & -1.445984 & 0.556947 & -2.596271 & $0.0094^{*}$ \\
ROA & 2.481042 & 1.236804 & 2.006010 & $0.0449^{*}$ \\
LN_TA & -3.252737 & 3.872054 & -0.840055 & 0.4009 \\
\hline \hline
\end{tabular}

Ket: ${ }^{*}=$ signifikan $5 \%$ 
Berdasarkan hasil analisis di atas diketahui bahwa kepemilikan LAZ mandiri (D_LAZ) dan Capital Adequacy Ratio (CAR) berpengaruh negatif dan signifikan, sedangkan Return on Asset (ROA) berpengaruh positif dan signifikan terhadap produktivitas sosial perbankan syariah. Kemudian, Financing to Deposit Ratio (FDR) dan ukuran bank (LN_TA) tidak berpengaruh signifikan atau tidak memberikan pengaruh yang nyata terhadap produktivitas sosial perbankan syariah.

Kepemilikan LAZ mandiri (D_LAZ) berpengaruh negatif dan signifikan terhadap produktivitas perbankan syariah yang dapat dilihat dari nilai koefisien -16.73544 dan Prob. Z < 5\%. Artinya semakin banyak bank syariah yang memiliki LAZ mandiri, maka akan semakin menurunkan tingkat produktivitas perbankan syariah dalam mengelola dana sosial, sebaliknya kerjasama perbankan syariah dengan LAZ independen untuk mengelola dana sosial akan semakin meningkatkan produktivitasnya. Temuan ini senada dengan amanah UU No. 21 tahun 2008 tentang perbankan syariah (RI, 2008). Adapun praktik mayoritas yang selama ini berjalan adalah perbankan syariah menjalin kerjasama dengan LAZ independen baik skala lokal maupun nasional untuk mentasharufkan dana zakat dan dana kebajikan yang dihimpun oleh perbankan syariah. Menurut peneliti, strategi ini sangat positif bagi perkembangan bisnis perbankan syariah, selain mampu melaksanakan kewajiban sosial, perbankan syariah juga terbantu oleh pihak eksternal dalam pengelolaan dana sosialnya tanpa takut tercampur antara proses bisnis perbankan dengan aktivitas sosialnya. Saat ini tercatat ada 3 Lembaga Amil Zakat (LAZ) yang terafiliasi dengan bank syariah, diantaranya adalah 1) Baitul maal muamalat, 2) Laznas BSM Umat, dan 3) Yayasan Hasanah Titik BNI Syariah.

FDR tidak berpengaruh signifikan terhadap produktivitas sosial perbankan syariah. Artinya, besaran dana yang disalurkan kepada masyarakat dari DPK tidak memiliki kontribusi yang nyata terhadap tingkat produktivitas sosial perbankan syariah. Hal ini dimungkinkan oleh kegiatan pembiayaan di perbankan syariah yang belum terintegrasi dengan kegiatan sosial (maal). Hasil ini tidak mendukung temuan Pambuko (2016), Sufian (2007), dan Sufian \&e Noor (2009).

CAR berpengaruh negatif dan signifikan terhadap produktivitas 
perbankan syariah yang dapat dilihat dari nilai koefisien -1.445984 dan Prob. $Z<5 \%$. Dengan kata lain semakin besar cadangan modal perbankan syariah untuk mengkover risiko akan semakin menurunkan tingkat produktivitas perbankan syariah dalam mengelola dana sosial. Berdasarkan hasil analisis MPI diketahui bahwa produktivitas perbankan syariah linear dengan tingkat efisiensi atau bank syariah yang telah efisien pasti akan produktif sehingga hal ini mungkin mencerminkan risk-return trade-off. Secara tidak langsung, hasil ini mendukung temuan Firdaus \& Hosen (2013) dan Frimpong et al., (2014) yang mengungkapkan bahwa CAR berpengaruh negatif terhadap tingkat efisiensi.

ROA berpengaruh positif dan signifikan terhadap produktivitas perbankan syariah yang dapat dilihat dari nilai koefisien 2.481042 dan Prob. Z < 5\%. Dengan kata lain semakin besar keuntungan yang diperoleh dari asset yang dikuasai akan membuat perbankan syariah semakin produktif dalam mengelola dana sosialnya. Sejalan dengan informasi pada pembahasan sebelumnya, secara tidak langsung temuan ini mendukung riset Firdaus $\&$ Hosen (2013), Pambuko (2016) dan Sufian (2007).
Ukuran bank tidak berpengaruh signifikan terhadap produktivitas sosial perbankan syariah. Artinya, ukuran bank syariah yang direfleksikan dari nilai asset tidak memiliki kontribusi yang nyata terhadap peningkatan produktivitas sosial perbankan syariah. Hal ini dimungkinkan bahwa ukuran bank tidak mencerminkan reputasi yang baik bagi perbankan syariah sehingga tidak memberikan dampak yang nyata terhadap tingkat produktivitas sosial dan dibuktikan dengan hasil analisis produktivitas dimana bank berskala besar seperti BRI Syariah mengalami penurunan produktivitas (0,963), sedangkan bank berskala kecil dan menengah seluruhnya meningkat produktivitasnya, seperti BJS Syariah, BCA Syariah, Bank Victoria Syariah, dan Bank Mega Syariah. Dalam perspektif keuangan, pelaporan juga dipisahkan antara neraca yang berkaitan dengan asset perbankan syariah dengan laporan zakat dan dana kebajikan sehingga memungkinkan kedua jenis dana dikelola secara parsial. Hasil ini tidak mendukung temuan Firdaus \& Hosen (2013).

\section{Kesimpulan}

Studi ini dilakukan untuk mengukur tingkat produktivitas 
perbankan syariah dalam mengelola dana sosial dan menganalisis determinan tingkat produktivitas tersebut pada periode 2013 - 2017 dengan pendekatan Two-Stage Malmquist Productivity Index. Langkah pertama menggunakan pendekatan Malmquist Productivity Index dan langkah selanjutnya menggunakan model pooled tobit.

Hasil pengujian pada tahap pertama menemukan bahwa perbankan syariah di Indonesia sepanjang periode 2013 - 2017 mengalami peningkatan produktivitas dalam mengelola dana sosial sebesar 33,2\% dimana tahun 20132014 menjadi periode yang paling produktif dibandingkan dengan periode setelahnya. Meningkatnya produktivitas sosial ini merupakan dampak dari perubahan teknologi sebesar $36,4 \%$ dan inefisiensi sebesar $-2.3 \%$. BJB Syariah menjadi bank syariah yang paling produktif dalam mengelola dana sosial dan BRI Syariah menjadi bank syariah yang tingkat produktivitasnya paling rendah.

Hasil pengujian pada tahap kedua menemukan bahwa kepemilikan LAZ mandiri (D_LAZ) dan Capital Adequacy Ratio (CAR) berpengaruh negatif dan signifikan, sedangkan Return on Asset (ROA) berpengaruh positif dan signifikan terhadap produktivitas sosial perbankan syariah. Kemudian, Financing to Deposit Ratio (FDR) dan ukuran bank tidak berpengaruh signifikan atau tidak memberikan pengaruh yang nyata terhadap produktivitas sosial perbankan syariah.

\section{DAFTAR PUSTAKA}

Afiatun, P., \& Wiryono, S. K. (2010). Efficiency and Productivity of Indonesian Islamic Banking. Jurnal Manajemen Teknologi, 9(3), 264-278.

Asian Banker Research. (2003). Bigger is Not Necessary Better: Bank Central Asia Outshines Bigger Players.

Bahrini, R. (2015). Productivity of MENA Islamic banks: a bootstrapped Malmquist index approach. International Journal of Islamic and Middle Eastern Finance and Management, https://doi.org/http://dx.doi.org/10.1 108/IMEFM-11-2014-0114

Banker, R. D., Charnes, A., \& Cooper, W. W. (1984). Some Models for Estimating Technical and Scale Inefficiencies in Data Envelopment Analysis. Management Science, 30(9), 1078-1092. https://doi.org/10.1287/mnsc.30.9.10 78

Coelli, T., Rao, P. D. S., O'Donnell, C. J., \& Battese, G. E. (2005). An Introduction to Efficiency and Productivity Analysis. Springer US. https://doi.org/10.1007/bl36381 
Endri. (2008). Efisiensi Teknis Perbankan Syariah di Indonesia. Finance and Banking Journal, 10(2).

Fare, R., Grosskopf, S., Norris, M., \& Zhang, Z. (1994). Productivity growth, technical progress and efficiency change in Industrialised Countries. The American Economic Review, 84(1), 66-83. https://doi.org/10.11l1/j.14678268.2004.00089.x

Fathony, M. (2012). Estimasi dan Faktor-Faktor yang Memengaruhi Efisiensi Bank Domestik dan Asing di Indonesia. Jurnal Keuangan dan Perbankan, 16(2), 223-237.

Firdaus, M. F., \& Hosen, M. N. (2013). Efisiensi Bank Umum Syariah Menggunakan Pendekatan TwoStage Data Envelopment Analysis. Bulletin Ekonomi Moneter dan Perbankan, 16(2), 167-188.

Frimpong, K. A., Gan, C., \& $\mathrm{Hu}, \mathrm{B}$. (2014). Cost Efficiency of Ghana's Banking Industry: A Panel Data Analysis. Business and Finance Research, 8(2), 69-86.

Hidayati, J. (2005). Analisis kinerja bank dengan DEA. Jurnal Sistem Teknik Industri, 6(2), 17-23.

Hseu, J. S., \& Shang, J. K. (2005). Productivity changes of pulp and paper industry in OECD countries, 1991-2000: A non-parametric Malmquist approach. Forest Policy and Economics, 7(3), 411-422. https://doi.org/10.1016/j.forpol.2003. 07.002

Hutabarat, J., \& Huseini, M. (2006).
Pengantar Manajemen Strategik

Kontemporer: Strategik di Tengah Operasional. Jakarta: PT. Elex Media Komputindo.

Johnes, J., Izzeldin, M., \& Pappas, V. (2015). Efficiency and productivity change in Islamic and conventional banks: Evidence from the Gulf Cooperation Council (GCC) countries. In 13th International Conference on Data Envelopment Analysis. Braunschweig: University of Huddersfield. Diambil dari http://eprints.hud.ac.uk/27824/

Kamarudin, F., Sufian, F., Loong, F. W., \& Anwar, N. A. M. (2017). Assessing the Domestic and Foreign Islamic Banks Efficiency: Insights from Selected Southeast Asian countries. Future Business Journal, 3(1), 33-46. https://doi.org/10.1016/j.fbj.2017.01.0 05

Kasmir. (2010). Bank dan Lembaga Keuangan Lainnya. Jakarta: PT. Raja Grafindo Persada.

Norfitriani, S. (2016). Analisis efisiensi dan produktivitas bank syariah di indonesia sebelum dan sesudah Spin Off. Jurnal Ekonomi Syariah Indonesia, 6(2), 134-143. Diambil dari

http://ejournal.almaata.ac.id/index. php/JESI/article/view/430

OJK. (2018). Statistik Perbankan Syariah Maret 2018. Jakarta.

Omar, A. M., Majid, M. S. A., \& Rulindo, R. (2007). Efficiency and Productivity Performance of The National Private Banks in 
Indonesia. Gadjah Mada International Journal of Business, 9(1), 1-18.

Othman, A., Kari, F., \& Hamdan, R. (2013). A Comparative Analysis of the Co-operative, Islamic and Conventional Banks in Malaysia. American Journal of Economics, 3(5C), 184-190.

https://doi.org/10.5923/c.economics .201301 .31

Pambuko, Z. B. (2016). Determinan Tingkat Efisiensi Perbankan Syariah di Indonesia $\square$ : Two Stages Data Envelopment Analysis. Cakrawala: Jurnal Studi Islam, XI(2), 178-194.

Pontoh, S. C. (2016). Tingkat Efisiensi Dan Total Produktivitas Bank Umum Syariah Di Indonesia Tahun 2010-2014 Menggunakan Pendekatan DEA Dan Malmquist Index. Arthavidya Jurnal Ekonomi, 18(2), 131-145. Diambil dari http://arthavidya.wisnuwardhana.a c.id/index.php/arthavidya/article/vi ew/8

Putra, R. R., Syifadhiya, S., Widyastiti, S. A., \& Pambuko, Z. B. (2018). Analisis Produktivitas Perbankan Syariah di Indonesia Dalam Mengelola Dana Sosial. Jurnal Ekonomi Syariah Indonesia, 8(1).

RI. Undang-undang Nomor 21 Tahun 2008 Tentang Perbankan Syariah (2008). Indonesia: Pemerintah Republik Indonesia.

Rivai, V., Veithzal, A. P., \& Idroes, F. N. (2007). Bank and Financial Institution Management. Jakarta: Rajawali Press.
Riyadi, S. (2015). Banking Assets And Liability Management,. Jakarta: Lembaga Penerbit Fakultas Ekonomi Universitas Indonesia.

Sufian, F. (2005). Sources of Productivity Changes of Commercial Banks in Developing Economy: Evidence from Malaysia, 1998-2003. International Journal of Applied Econometrics and Quantitative Studies, 2(3), 87-100.

Sufian, F. (2007). Malmquist Indices of productivity Change in Malaysian Islamic Banking Industry: Foreign Versus Domestic Banks. Journal of Economic Cooperation, 28(1), 115-150. https://doi.org/10.1007/BF02294970

Sufian, F., \& Kamarudin, F. (2017). Forced Mergers on Bank Efficiency and Productivity: Evidence from Semi-parametric Malmquist Productivity. Global Business Review, 18(1).

https://doi.org/https://doi.org/10.117 7/0972150916666850

Sufian, F., \& Noor, M. A. N. M. (2009). The Determinants of Islamic Banks' Efficiency Changes Empirical Evidence from the MENA and Asian Banking Sectors. International Journal of Islamic and Middle Eastern Finance and Management, 2(2), 120138.

Suzuki, Y., \& Sastrosuwito, S. (2011). Efficiency and Productivity Change of the Indonesian Commercial Banks. In International Conference on Economics, Trade and Development IPEDR. Vol. 7. 